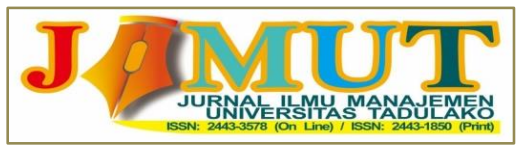

Vol. 7, No 3, Juli 2021, 237-247

\title{
PENGARUH KUALITAS LAYANAN DAN PEMANFAATAN KOLEKSI BUKU TERHADAP MINAT BERKUNJUNG KEMBALI PADA PERPUSTAKAAN SMA NEGERI 6 SIGI
}

\author{
Sitti Nur Faizah \\ Maskuri Sutomo \\ Program Studi S1 Manajemen Fakultas Ekonomi Universitas Tadulako \\ email: stnurfaizah682@gmail.com;maskuri.sutomo@yahoo.com
}

\begin{abstract}
This study aims to determine the influence of Service Quality given by Librarian as library implementers to users at SMAN Sigi 6 Public High School library. This research is a verification study or finding out the relations or the influence between independent variables and dependent variable using a quantitative approach. This research was conducted at library of SMAN 6 Sigi. The population in this study was 775 people and 88 samples were taken using systematic sampling techniques. Data collection used was questionnaire and documentation method. Analysis technique used was multiple linear regression analysis with the help of SPSS 21 for Windows. The result shows that service quality and the utilization of book collections simultaneously had a significant influence to the interest on library re-visiting at SMAN 6 Sigi with a magnitude of influence is 0.185 or $18.5 \%$. The service quality has a significant influence to the interest on library re-visiting at SMAN 6 Sigi with significant value smaller than the $\alpha$ value of $0,000<0.05$, with a magnitude of influence is 0.406 or $40.6 \%$.
\end{abstract}

Keywords: Service Quality, Utilization of Collection, and Interest of Re-visiting

\begin{abstract}
Abstrak
Penelitian ini bertujuan untuk mengetahui pengaruh pelayanan yang diberikan oleh pemustaka selaku pelaksana perpustakaan terhadap pengguna di perpustakaan SMAN 6 Sigi. Penelitian ini merupakan penelitian verifikatif atau mencari tahu hubungan atau pengaruh antara variabel bebas terhadap variabel terikat dengan menggunakan pendekatan kuantitatif. Penelitian ini dilakukan di perpustakaan SMAN 6 Sigi. Jumlah populasi dalam penelitian ini adalah 775 orang dan sampel yang diambil sebanyak 88 orang yang ditarik menggunakan teknik systematic sampling. Pengumpulan data menggunakan metode angket dan dokumentasi. Dan teknik analisa yang digunakan adalah analisis regresi linear berganda dengan program SPSS 21 For Windows. Hasil penelitian menunjukkan bahwa kualitas pelayanan dan pemanfaatan koleksi buku secara serempak memiliki pengaruh signifikan terhadap minat berkunjung kembali pada perpustakaan SMAN 6 Sigi dengan besaran pengaruh sebesar 0,185 atau $18,5 \%$. Kualitas layanan berpengaruh signifikan terhadap minat berkunjung kembali pada perpustakaan SMAN 6 Sigi dengan nilai sig lebih kecil daripada nilai $\alpha$ yaitu $0.000<$ 0,05 , dengan besaran pengaruh yaitu 0,406 atau $40,6 \%$.
\end{abstract}

Kata Kunci : Kualitas Layanan, Pemanfaatan Koleksi, dan Minat Berkunjung Kembali

\section{PENDAhULUAN}

Pendidikan merupakan bagian penting pada perkembangan siswa, sehingga banyak siswa yang ingin menuntut ilmu setinggi-tingginya. Salah satu sarana penting yang dijadikan sebagai dasar utama pendidikan perpustakaan. Perpustakaan merupakan tempat atau ruangan yang memiliki banyak koleksi bacaan yang dapat memberikan informasi dan ilmu untuk siswa. Sejalan dengan perkembangan zaman, teknologi yang berkembang pesat berpengaruh terhadap minat siswa dalam melakukan kunjungan ke perpustakaan, sehingga banyak siswa yang belum bisa memanfaatkan perpustakaan secara baik. Padahal melalui buku-buku yang terdapat di perpustakaan mereka akan lebih mendapatkan banyak ilmu pengetahuan serta wawasan yang luas. 
Menurut Hernandono (1999:17) berhasil tidaknya pelayanan perpustakaan dapat dilihat dari jumlah buku yang dipinjam dan dibaca. Walaupun memiliki koleksi yang banyak, bahannya mahal tetapi bila tidak dimanfaatkan belum dapat dikatakan berhasil untuk itu koleksi buku teks pelajaran harus sesuai dengan keinginan pengguna. Untuk itu perpustakaan SMA NEGERI 6 SIGI berusaha menyediakan berbagai sumber informasi yang up to date untuk memenuhi kebutuhan kurikulum sekolah dan kebutuhan lainnya.

Menurut Kotler (2002:83) kualitas layanan merupakan tindakan atau kegiatan yang diberikan oleh suatu pihak kepada pihak lain, yang pada dasarnya tidak berwujud dan tidak mengakibatkan kepemilikan apa pun. Pelayanan yaitu suatu perilaku seseorang untuk memenuhi kebutuhan serta keinginan konsumen agar tercapainya kepuasan kepada konsumen itu sendiri. Sehingga kualitas layanan yang baik diyakini mampu meningkatkan minat siswa untuk berkunjung kembali, untuk setiap perpustakaan harus berusaha memberikan kualitas layanan yang terbaik. Pengunjung perpustakaan yang telah memperoleh sikap dan pelayanan yang baik dari pengelola perpustakaan tentu akan menimbulkan persepsi yang baik dari pengunjung. Akibatnya perpustakaan tersebut akan selalu dikunjungi oleh siswa sehingga secara otomatis dapat meningkatkan daya guna perpustakaan tersebut. Oleh karena itu, perpustakaan seharusnya selalu menjaga kualitas layanannya.

Menurut Parasuraman, Valerie A, Zeithaml dan Leonard L. Berry, (1985:41-50). Terdapat 5 dimensi dalam menentukan kualitas layanan yang pertama adalah: bukti fisik, kehandalan, ketanggapan, jaminan dan empati. Jika dikaitkan dengan kondisi yang ada pada SMA Negeri 6 Sigi, dapat dilihat bahwa

bukti fisik (Tangibles) Fasilitas dan perlengkapan yang diberikan perpustakaan namun jika dilihat dari fasilitasnya masih kurang lengkap seperti (kipas angin/AC, komputer, internet).

Kehandalan (reliability) yang dapat dilihat dari kemampuan perpustakaan untuk memberikan pelayanan yang sesuai pada perpustakaan dengan waktu pelayanan mulai dari pukul $08.00-14.00$ selama aktivitas sekolah, kehandalan dalam perpustakaan ini juga memberikan kemudahan kepada siswa dalam melakukan administrasi. Akan tetapi dalam pelayanan ini sering terjadi keterlambatan dalam melakukan pelayanan misalnya siswa yang ingin melakukan peminjaman buku atau melakukan pengembalian buku petugas perpustakaan tidak ada di tempat sehingga mengakibatkan lambatnya proses pelayanan kepada pengunjung perpustakaan.

Daya tanggap (Responsiveness) membantu dan memberikan pelayanan yang cepat kepada siswa yang berkunjung pada perpustakaan. Mendengar dan mengatasi keluhan-keluhan yang diajukan siswa terhadap pelayanan yang diberikan pihak perpustakaan. Sehingga pengelola perpustakaan tanggap dalam memberikan informasi kepada siswa mengenai informasi yang ada pada perpustakaan serta membantu kesulitan siswa seperti dalam melakukan peminjaman buku namun siswa tersebut belum mempunyai kartu anggota perpustakaan sehingga pengelola dapat memberikan kemudahan kepada siswa tersebut dengan memberikan kebijakan dalam artian memberikan keterangan pinjaman kepada siswa kemudian membuat kartu anggota perpustakaan.

Jaminan (assurance) mencakup pengetahuan dan memberi rasa aman serta kemampuan melaksanakan tugas secara spontan yang dapat menjamin kerja baik, sehingga menimbulkan kepercayaan dan keyakinan kepada siswa yang berkunjung ke perpustakaan. Dimana tingkat pengetahuan mereka akan menunjukkan tingkat kepercayaan bagi pengunjung sikap ramah, sopan, dan bersahabat menunjukkan perhatian pada minat pengunjung perpustakaan untuk memanfaatkan kembali koleksi buku yang ada.

Empati (Empathy) usaha dalam memberikan jaminan yang bersifat individual atau pribadi kepada pengunjung dan berupaya untuk memahami keinginan dan kebutuhan siswa yang berkunjung di perpustakaan. Tingkat kepedulian dan perhatian petugas perpustakaan kepada pengunjung untuk 
mewujudkan layanan prima diciptakan kesan yang menarik dan menyenangkan penerima layanan, salah satunya dapat diwujudkan dengan memberikan perhatian personal terhadap pengunjung dalam memahami kebutuhannya. Misalnya memberi masukan bahan bacaan yang sesuai dengan kurikulum pembelajaran yang ditetapkan di perpustakaan.

\section{KAJIAN LITERATURE}

\section{Kualitas Layanan}

Ariyani (2010:115) menjelaskan bahwa Kualitas layanan mendorong pelanggan untuk berkomitmen kepada produk dan layanan suatu perusahaan sehingga berdampak kepada peningkatan market share suatu produk. Kualitas layanan sangat krusial mempertahankan pelanggan dalam waktu yang lama sehingga perusahaan yang memiliki layanan superior akan dapat memaksimalkan performa keuangan perusahaan. Kualitas pelayanan dalam hal ini harus ada di dalam perpustakaan sehingga dengan adanya kualitas layanan maka pemustaka akan merasa diperhatikan dan akan sering berkunjung ke perpustakaan.

\section{Jenis-jenis Layanan Perpustakaan}

Perpustakaan sekolah pada umumnya memiliki layanan peminjaman (sirkulasi), layanan rujukan (referensi), layanan baca dan layanan bimbingan/ konsultasi. Secara garis besar, jenis-jenis layanan perpustakaan sekolah akan diuraikan sebagai berikut:

1. Layanan Peminjaman

Layanan peminjaman merupakan pemberian layanan dengan meminjamkan bahan pustaka kepada pemakai untuk bisa dibawa pulang. Layanan ini sering dikenal dengan sebutan layanan sirkulasi peminjaman sehingga layanan inilah yang pertama kali berhubungan dengan pemustaka serta paling sering digunakan oleh pemustaka.

2. Layanan Rujukan

Layanan rujukan atau layanan referensi disediakan untuk membantu pemustaka menelusuri informasi dalam berbagai subjek. Dengan pelayanan inilah pemustaka dibantu untuk menemukan informasi dengan cepat dan menelusuri informasi dengan pilihan subjek yang luas.

3. Layanan Pembaca

Suherman (2009:124) layanan pembaca merupakan kegiatan pemberian layanan kepada pengunjung perpustakaan sekolah dalam menggunakan buku-buku dan bahan-bahan pustaka lainnya. Pengunjung perpustakaan sekolah pada dasarnya meliputi murid-murid, guru-guru, dan anggota staf sekolah lainnya. Pelayanan kepada pengunjung tersebut dapat diselenggarakan dengan sebaik-baiknya.

4. Layanan Sirkulasi

Lasa (2009:249) pelayanan sirkulasi yang dimaksudkan sebagai jenis pelayanan dalam pendayagunaan serta pemanfaatan koleksi perpustakaan sekolah secara optimal oleh para pemustaka perpustakaan, termasuk didalamnya para peserta didik. Oleh karena itu, dalam pelayanan sirkulasi, harus dilakukan dengan tepat, cepat, dan mengenai sasaran yang diinginkan.

\section{Pemanfaatan Koleksi}

Istiawan (2014:3) menjelaskan bahwa pemanfaatan koleksi yang dilakukan pemustaka menggambarkan peran perpustakaan yang menjadi hal penting dan dibutuhkan dalam perpustakaan agar pemustaka dapat memperoleh informasi sesuai dengan bahan koleksi yang digunakan atau yang dimanfaatkan untuk menambah pengetahuan baru yang diinginkan. 


\section{Jenis-jenis Koleksi}

Koleksi merupakan daya tarik utama dari sebuah perpustakaan. Salah satu aspek penting untuk membuat perpustakaan banyak digunakan oleh pemustaka adalah ketersediaan koleksi yang memadai dan memenuhi kebutuhan.

Mathar (2012:114) secara sederhana menjelaskan bahwa koleksi perpustakaan dibedakan menjadi dua jenis yakni Koleksi Umum dan Koleksi Khusus.

1. Koleksi Umum

Koleksi ini tersimpan dalam rak secara terbuka dan dapat langsung diambil oleh pemustaka untuk dibaca diruang perpustakaan atau dipinjam. Koleksi umum sebagian besar berbentuk buku, tersusun menurut sistem klasifikasi yang telah ditentukan yang akan memudahkan setiap pemustaka melakukan penelusuran kembali secara efektif dan efisien.

2. Koleksi Khusus

Merupakan koleksi yang mendapat perlakuan khusus yang memiliki nilai lebih dibandingkan dengan koleksi lain yang ada di perpustakaan. Koleksi khusus yang dimaksud dalam suatu perpustakaan perguruan tinggi yaitu seperti skripsi, disertasi, laporan penelitian dan beberapa koleksi khusus lainnya.

Menurut Almah (2012:25), secara garis besar terdapat berbagai jenis koleksi bahan pustaka, hasil karya pemikiran manusia yang dituangkan kedalam berbagai jenis media baik cetak maupun non cetak.

\section{Minat Berkunjung}

Habir (2015:159) menjelaskan bahwa minat seseorang terhadap suatu objek akan lebih kelihatan apabila objek tersebut sesuai dengan sasaran dan berkaitan dengan keinginan dan kebutuhan orang yang bersangkutan.

Faktor-faktor yang mempengaruhi minat kunjung pemustaka ke perpustakaan adalah sebagai berikut:

1. Kondisi fisik, keadaan jasmani dan kondisi yang baik akan mempengaruhi minat yang lebih tinggi. Namun setelah adanya peristiwa, sehingga mengakibatkan seseorang mengalami cacat jasmani maka orang tersebut akan berubah minat belajarnya sehingga lebih suka kepada halhal yang sesuai dengan kondisi dirinya.

2. Keadaan psikis, perubahan psikis seseorang mempengaruhi minat terhadap suatu bidang studi tertentu, misalnya dalam gangguan jasmani dan rohaninya, maka akan mempengaruhi keinginan yang berbeda.

3. Lingkungan sosial, lingkungan atau alam sekitar akan mempengaruhi minat meskipun dalam waktu yang relatif lama.

\section{METODE PENELITIAN}

jenis penelitian Verifikatif. Menurut Sugiyono (2013:206) penelitian verifikatif merupakan penelitian yang bertujuan untuk mengetahui hubungan antara dua variabel atau lebih melalui pengumpulan data di lapangan dilakukan terhadap populasi atau sampel tertentu dengan tujuan untuk menguji hipotesis yang telah ditetapkan atau mencari pengaruh antara variabel bebas terhadap variabel terikat. Penelitian ini dilakukan menggunakan kuesioner sebagai alat pengumpul data. Kuesioner dalam penelitian ini terdiri dari daftar butir-butir pertanyaan atau pernyataan yang dibagikan kepada responden untuk mengumpulkan data.

Penelitian ini bertempat di perpustakaan SMA Negeri 6 Sigi berlokasi di Jl. Tadulako Trans Palu-Napu Desa Ampera Kecamatan palolo

Populasi dalam penelitian ini adalah adalah seluruh peserta didik/pengguna perpustakaan SMA Negeri 6 Sigi dengan jumlah 775 orang. Pemilihan sampel dalam penelitian ini dilakukan dengan menggunakan teknik systematic sampling. Teknik systematic sampling yaitu teknik 
pengambilan sampel berdasarkan urutan dari anggota populasi dengan cara pengambilan sampel dapat dilakukan dengan nomor ganjil, genap, atau kelipatan dari bilangan tertentu adapun cara kerjanya yaitu terlebih dahulu membuat daftar populasi dengan menggunakan nomor secara berurutan, penentuan siapa yang akan menjadi nomor satu, dua, dan seterusnya dari populasi itu hendaklah ditentukan secara random. Kemudian menentukan interval (i) yang merupakan perbandingan antara jumlah populasi dan ukuran atau besarnya sampel yang telah ditentukan. Sampel pada penelitian adalah seluruh peserta didik SMA Negeri 6 Sigi sehingga diperoleh jumlah sampel 88 siswa.

\section{HASIL DAN PEMBAHASAN}

Penelitian ini dilakukan pada Sekolah SMA Negeri 6 Sigi yang beralamat di Jl. Tadulako Trans Palu-Napu Desa Ampera Kecamatan Palolo Provinsi Sulawesi Tengah. Data penelitian menggunakan instrumen kuesioner yang dibagikan kepada siswa yang terdiri dari 2 jurusan sebagai sampel penelitian.

Kuesioner dibagikan peneliti kepada responden yang diteliti sesuai deskripsi sebagai berikut:

Tabel 1. Deskripsi Kuesioner

\begin{tabular}{ccccc}
\hline $\begin{array}{c}\text { Jumlah } \\
\text { Sampel }\end{array}$ & $\begin{array}{c}\text { Kuesioner } \\
\text { Disebar }\end{array}$ & $\begin{array}{c}\text { Kuesioner } \\
\text { Kembali }\end{array}$ & $\begin{array}{c}\text { Kuesioner } \\
\text { Diolah }\end{array}$ & Persentase \\
\hline 88 & 88 & 88 & 88 & $100 \%$ \\
\hline
\end{tabular}

Sumber: Data, diolah (2019)

Berdasarkan tabel 1 dijelaskan bahwa jumlah sampel pada penelitian yang dilakukan yaitu 88 orang siswa.

Tabel 2.

Karakteristik Responden Berdasarkan Jenis Kelamin

\begin{tabular}{cccc}
\hline No & Jenis Kelamin & Jumlah & Persentase \\
\hline 1 & Laki-laki & 25 & $28 \%$ \\
2 & Perempuan & 63 & $72 \%$ \\
& Jumlah & 88 & $100 \%$ \\
\hline
\end{tabular}

Sumber: Data, diolah (2019)

Berdasarkan tabel 2, Menunjukkan bahwa dari 88 orang jumlah sampel terdapat 25 orang $28 \%$ yang berjenis kelamin laki-laki sedangkan 63 orang $72 \%$ perempuan sehingga sampel lebih dominan berjenis kelamin perempuan.

Tabel 3.

Responden Berdasarkan Jurusan

\begin{tabular}{cccc} 
NO & Jurusan & Jumlah & Persentase \\
\hline 1 & IPA & 43 & $49 \%$ \\
2 & IPS & 45 & $51 \%$ \\
& Jumlah & 88 & $100 \%$ \\
\hline
\end{tabular}

Sumber: Data, diolah (2019)

Berdasarkan tabel 3, menunjukkan jumlah responden dari beberapa jurusan, dimana responden terbanyak berasal dari jurusan Ilmu Pengetahuan Sosial (Ips) sebanyak 45 responden (51\%), 
kemudian dari jurusan Ilmu Pengetahuan Alam (Ipa) sebanyak 43 responden (49\%), Sehingga sampel terbanyak dari jurusan Ips dengan 45 responden (51\%).

Tabel 4

Responden Berdasarkan Kelas

\begin{tabular}{cccc} 
No & Kelas & Jumlah & Persentase \\
\hline 1 & XI & 41 & $47 \%$ \\
2 & XII & 47 & $53 \%$ \\
& Jumlah & 88 & $100 \%$ \\
\hline
\end{tabular}

Sumber: Data, diolah (2019)

Berdasarkan tabel 4, menunjukkan jumlah responden dari setiap kelas, dimana responden terbanyak berasal dari kelas XII yaitu sebanyak 47 responden (53\%), kemudian dari kelas XI sebanyak 41 responden (47\%), sehingga sampel dalam penelitian ini terbanyak dari kelas XII dengan 47 responden $(53 \%)$.

Tabel 5

Responden Berdasarkan Semester

\begin{tabular}{cccc} 
No & Semester & Jumlah & Persentase \\
\hline 1 & 3 & 43 & $49 \%$ \\
2 & 5 & 45 & $51 \%$ \\
& Jumlah & 88 & $100 \%$ \\
\hline
\end{tabular}

Sumber: Data, diolah (2019)

Berdasarkan tabel 5.5 menunjukkan jumlah responden dari setiap semester, dimana responden terbanyak berasal dari semester 5 yaitu sebanyak 45 responden (51\%), kemudian dari semester 3 sebanyak 43 responden (49\%), sehingga sampel dalam penelitian ini terbanyak dari semester 5 dengan 45 responden $(51 \%)$ 


\section{Analisis Regresi Linear Berganda}

Analisis regresi linear berganda adalah salah satu alat statistik non parametrik yang berfungsi menganalisis keterkaitan dan hubungan di antara dua atau lebih variabel penelitian yang berbeda, yaitu variabel dependen dan independen. Selanjutnya dari hasil analisis regresi berganda ini akan diketahui ada tidaknya pengaruh secara parsial dan serempak variabel kualitas layanan (X1), Pemanfaatan Koleksi Buku (X2), terhadap Minat Berkunjung Kembali (Y).

Berdasarkan hasil olah data menggunakan SPSS 21 for Windows diperoleh hasil analisis regresi berganda sebagai berikut.

Tabel 6

Hasil Analisis Regresi Linear Berganda

\begin{tabular}{|c|c|c|c|c|c|c|c|c|}
\hline & \multirow{3}{*}{ Model } & \multirow{2}{*}{\multicolumn{2}{|c|}{$\begin{array}{l}\text { Unstandardiz } \\
\text { ed } \\
\text { Coefficients }\end{array}$}} & \multirow{3}{*}{$\begin{array}{c}\text { Standardize } \\
\text { d } \\
\text { Coefficients } \\
\text { Beta }\end{array}$} & \multirow[t]{3}{*}{$\mathrm{T}$} & \multirow[t]{3}{*}{ Sig. } & \multicolumn{2}{|c|}{$\begin{array}{l}\text { Collinearity } \\
\text { Statistics }\end{array}$} \\
\hline & & & & & & & & \\
\hline & & B & $\begin{array}{l}\text { Std. } \\
\text { Error }\end{array}$ & & & & $\begin{array}{c}\text { Toleranc } \\
\text { e }\end{array}$ & VIF \\
\hline \multirow{4}{*}{1} & (Constant) & 9,367 & 3.000 & & 3.122 & .002 & & \\
\hline & Kualitas & .109 & .029 & .406 & 3.787 & .000 & .833 & 1.200 \\
\hline & Layanan & & & & & & & \\
\hline & $\begin{array}{l}\text { Pemanfataan } \\
\text { Koleksi Buku }\end{array}$ & .013 & .027 & .053 & .490 & .625 & .833 & 1.200 \\
\hline
\end{tabular}

Sumber: Data, diolah dengan Spps (2019)

Hasil analisis regresi linear berganda pada tabel di atas, kemudian dimasukkan ke dalam model persamaan regresi berganda sebagai berikut:

$\mathrm{Y}=9,367+0,109_{\mathrm{X} 1}+0,013_{\mathrm{X} 2}$

Dari persamaan regresi linear berganda tersebut dapat dijelaskan sebagai berikut:

1. Konstanta positif mempunyai arti minat berkunjung kembali siswa akan meningkat jika variabel kualitas layanan, dan pemanfaatan koleksi buku, konstan atau bernilai nol (0).

2. Koefisien regresi Kualitas Layanan (X1) bernilai positif. Nilai positif (+) pada variabel kualitas layanan, artinya bahwa setiap terjadinya peningkatan satu satuan variabel layanan (X1) maka akan meningkatkan minat berkunjung kembali.

Koefisien regresi Pemanfaatan Koleksi Buku (X2) bernilai positif. Nilai positif (+) pada variabel Pemanfaatan Koleksi Buku, artinya bahwa setiap terjadinya peningkatan satu satuan variabel Pemanfaatan Koleksi Buku (X2) akan meningkatkan Minat Berkunjung Kembali.

Hasil pengujian dengan menggunakan analisis regresi berganda dengan bantuan SPSS 21 for Windows, menunjukkan bahwa secara serempak variabel $\mathrm{X} 1$ dan $\mathrm{X} 2$ memiliki pengaruh positif terhadap minat berkunjung kembali siswa pada perpustakaan SMA Negeri 6 Sigi. Begitu pula dengan pengaruh masing-masing variabel secara parsial masing-masing memiliki pengaruh dengan besaran pengaruh yang berbeda. 


\section{Pengaruh Kualitas Layanan Terhadap Minat Berkunjung Kembali .}

Kualitas layanan merupakan hal yang paling awal dinilai dari para konsumen atau pengunjung. Di sebuah perpustakaan yang menyediakan berbagai macam produk atau buku-buku sebagai bahan bacaan, petugas perpustakaan memberikan perhatian khusus kepada pengunjung agar layanan yang diberikan dapat dirasakan pengunjung dengan baik.

Berdasarkan hasil pengujian terbukti adanya pengaruh signifikan kualitas layanan yang terdiri dari dimensi bukti fisik, kehandalan, daya tanggap, jaminan, dan empati terhadap minat berkunjung kembali. Kesimpulan ini berdasarkan nilai yang diperoleh dari penjelasan regresi linear berganda yang memberikan makna bahwa secara parsial variabel Kualitas Layanan (X1) memberikan pengaruh positif terhadap Minat Berkunjung Kembali (Y)

Hal ini menggambarkan bahwa dimensi yang ada pada kualitas layanan memberikan kontribusi besar sebagai suatu yang positif dan dapat menciptakan minat berkunjung siswa. Terbentuknya minat siswa berawal dari layanan yang baik yang dirasakan oleh pengunjung perpustakaan. Terciptanya minat berkunjung kembali siswa dapat dilihat pada data yang diperoleh dari hasil penelitian yang dapat menunjukkan indikator-indikator disetiap variabel yang memiliki nilai loading faktor yang baik, ini menunjukkan bahwa berdasarkan penelitian diketahui bahwa kualitas layanan terbentuk dari dimensi bukti fisik, kehandalan, daya tanggap, jaminan, dan empati berpengaruh signifikan dan positif terhadap minat berkunjung kembali.

Hal tersebut ditunjang dengan adanya dimensi yang memberikan kontribusi terbesar terhadap kualitas layanan yaitu bukti fisik. Dimensi ini terdapat indikator yang memberikan kontribusi terbesar yang menunjang yaitu petugas mengatur ruangan dengan baik. Ini berarti bahwa petugas perpustakaan cepat dalam memberikan pelayanan terhadap pengunjung, sehingga pengunjung merasa puas dan senang berkunjung karena dari segi pelayanan yang baik pada perpustakaan.

Hasil penelitian sejalan dengan penelitian yang dilakukan oleh Habir (2015) meneliti tentang pengaruh layanan terhadap minat kunjung pemustaka di perpustakaan Stikes Mega Rezky Makassar, yang menunjukkan bahwa variabel kualitas layanan berpengaruh positif terhadap minat berkunjung pada perpustakaan Stikes Mega Rezky Makassar.

Hal ini diperkuat oleh teori Kotler (1997) mengatakan bahwa untuk meningkatkan kepuasan pelanggan serta mempertahankan dalam jangka panjang, perusahaan perlu menambahkan minat kunjung kembali pada pengguna jasa yang ditawarkan. Menambahkan minat kunjung kembali akan membuat pengguna jasa merasa bahwa mereka mendapat lebih dari apa yang mereka harapkan.

Kualitas layanan menjadi faktor yang mempengaruhi minat siswa dalam berkunjung. Kualitas layanan merupakan hal yang harus ada didalam perpustakaan umum dengan adanya kualitas maka pemustaka akan merasa diperhatikan dan akan sering berkunjung ke perpustakaan.

\section{Pengaruh Pemanfaatan Koleksi Buku Terhadap Minat Berkunjung Kembali}

Berdasarkan hasil penelitian diketahui bahwa pengaruh pemanfaatan koleksi buku terhadap minat berkunjung kembali yang didapatkan dari penelitian ini adalah bahwa tidak terdapat pengaruh yang signifikan antara kedua variabel yang ditunjukkan pada penjelasan regresi linear berganda dengan nilai ini memberikan makna bahwa variabel Pemanfaatan Koleksi Buku (X2) tidak memberikan pengaruh signifikan terhadap minat berkunjung kembali $(\mathrm{Y})$. Hal ini disebabkan karena adanya faktor yang mempengaruhi diluar dari penelitian yaitu salah satunya faktor dari sumber daya manusia atau siswanya itu sendiri yang malas dan juga faktor semakin berkembangnya teknologi sehingga siswa lebih memanfaatkan informasi teknologi daripada memanfaatkan koleksi buku langsung.

Dengan demikian rumusan masalah ketiga yang mempertanyakan: apakah pemanfaatan koleksi buku berpengaruh terhadap minat berkunjung kembali siswa SMA Negeri 6 Sigi? Sudah terjawab, 
maka hipotesis ketiga yang menyatakan bahwa pemanfaatan koleksi buku berpengaruh terhadap minat berkunjung kembali ditolak.

Hal ini menggambarkan bahwa indikator yang ada pada pemanfaatan koleksi buku memberikan kontribusi kecil yang menciptakan keinginan siswa untuk bekunjung kembali. Minat siswa dalam berkunjung kembali dapat dilihat pada data yang diperoleh dari hasil penelitian yang dapat menunjukkan indikator-indikator disetiap vaiabel memiliki nilai loading factor yang baik meskipun terdapat beberapa tanggapan siswa yang kurang baik atau kurang setuju pada setiap indikator tersebut. Ini menunjukkan bahwa berdasarkan penelitian diketahui bahwa pemanfaatan koleksi buku yang terbentuk dari beberapa indikator tidak berpengaruh signifikan terhadap minat berkunjung kembali.

Hal tersebut ditunjang dengan adanya indikator yang memberikan kontribusi kecil terhadap minat berkunjung kembali yaitu memanfaatkan koleksi buku sebagai hiburan.

Penelitian ini tidak sejalan dengan penelitian yang dilakukan oleh Hesti (2014) meneliti tentang Pemanfaatan Koleksi Buku Perpustakaan Sekolah Oleh Siswa di SMA Negeri 1 Kalasan yang menunjukkan bahwa terdapat pengaruh pada pemanfaatan koleksi buku, sehingga dalam penelitian ini bertolak belakang dengan penelitian yang dilakukan yaitu tidak adanya pengaruh yang signifikan terhadap minat berkunjung kembali.

Dapat diketahui bahwa manfaat koleksi buku perpustakaan sekolah bagi siswa pada umumnya bermanfaat sebagai sumber informasi untuk menyelesaikan tugas dari guru maupun untuk menambah pengetahuan. Dari hasil wawancara dengan beberapa siswa, umumnya siswa memanfaatkan koleksi buku perpustakaan sekolah untuk kepentingan kegiatan belajar di kelas dan untuk menyelesaikan tugas dari guru. Perpustakaan sekolah memiliki koleksi buku penunjang pelajaran yang cukup beragam sehingga dapat menunjang kegiatan belajar di sekolah.

Menurut beberapa siswa, guru memberikan tugas kepada siswanya dalam bentuk PR (pekerjaan rumah) atau tugas di kelas dan jarang memberikan tugas penulisan karya ilmiah sehingga koleksi buku kurang dimanfaatkan untuk penulisan karya ilmiah. Biasanya guru memberikan tugas penulisan karya ilmiah jika ada kegiatan pelombaan di sekolah, itu pun tidak ke semua siswa hanya ke beberapa siswa saja yang akan mengikuti perlombaan. Sehingga siswa jarang memanfaatkan koleksi buku untuk penulisan karya ilmiah.

Sesuai dengan hasil jawaban responden yang ada bahwa, 49 responden atau 55,7\% yang sangat setuju dengan pernyataan petugas mengatur ruangan dan buku dengan baik, 46 responden atau 52,2\% yang sangat setuju dengan pernyataan memanfaatkan koleksi buku untuk menambah wawasan, dan juga terdapat 53 responden atau $60,2 \%$ yang sangat setuju dengan pernyataan saya berkunjung ke perpustakaan untuk memperoleh informasi. Hal dianggap telah menjadi pendorong siswa untuk melakukan kunjungan kembali pada perpustakaan SMA Negeri 6 Sigi.

Berdasarkan hasil analisis dari jawaban responden tersebut, seharusnya kualitas layanan menjadi salah satu alasan mereka untuk melakukan kunjungan kembali pada perpustakaan SMA Negeri 6 Sigi, kaena kualitas layanan yang ditawarkan telah sesuai dengan yang mereka harapkan. Jika petugas perpustakaan lebih meningkatkan kualitas layanan dari berbagai aspek yang diberikan, maka akan dapat meningkatkan minat berkunjung kembali di perpustakaan tersebut. 


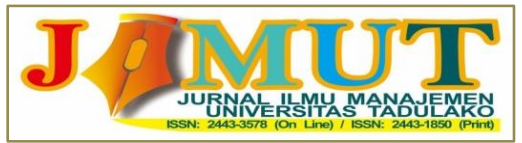

Vol. 7, No 3, Juli 2021, 237-247

\section{KESIMPULAN DAN SARAN}

Berdasarkan hasil penelitian pada bab V dapat disimpulkan bahwa :

1. Kualitas layanan dan pemanfaatan koleksi buku secara serempak memiliki pengaruh signifikan terhadap minat berkunjung kembali pada perpustakaan SMA Negeri 6 Sigi.

2. Kualitas layanan mempunyai pengaruh signifikan terhadap minat berkunjung kembali pada perpustakaan SMA Negeri 6 Sigi.

3. Pemanfaatan koleksi buku tidak berpengaruh signifikan terhadap minat berkunjung kembali pada perpustakaan SMA Negeri 6 Sigi

Hasil penelitian memiliki beberapa saran: (1) Pemanfaatan koleksi perpustakaan di perpustakaan SMA Negeri 6 Sigi hendaknya dapat lebih ditingkatkan lagi dalam mutu koleksinya, yaitu menambah jenis koleksi. Pustakawan juga sebaiknya menghimbau dan membantu siswa yang belum memiliki kartu anggota perpustakaan sehingga semua siswa dapat memanfaatkan seluruh layanan dan fasilitas perpustakaan termasuk koleksi buku secara maksimal. (2) Menyediakan komputer agar mempermudah pustakawan dibagian sirkulasi dan pemustaka menelusuri informasi tanpa ada hambatan. (3) Untuk peneliti berikutnya, juga dapat memberikan alternatif tambahan lainnya yaitu menambah variabel penelitian agar penelitian serupa lebih baik lagi dan lebih bervariatif.

\section{REFERENSI}

Algifari. (2016). Mengukur Kualitas Layanan dengan Indeks Kepuasan, Metode ImportancePerformance Analysis (IPA), dan Model Kano. Yogyakarta: BPFE.

Ariyani, Dwi. 2010. Pengaruh Kualitas Layanan Terhadap Kepuasan Pelanggan dalam Membentuk Loyalitas Pelanggan. Jurnal Ilmu Administrasi dan Organisasi. Vol.17, No. 2, h.115.

Almah, Hildawati. 2012. Pemilihan Dan Pengembangan Koleksi Perpustakaan, Alauddin University Press, Makassar.

Adin, Anissa Kusuma. 2009. Pengaruh Kualitas Layanan Referensi Menggunakan Libqual+® Terhadap Kepuasan Pengguna Di Perpustakaan Universitas s Kristen. Petra Surabaya, h.2.

Arikunto, 2010. Prosedur Penelitian: suatu pendekatan praktek, Rineka Cipta, Jakarta.

Basuki, Sulistyo. 1993. Pengantar Ilmu Perpustakaan, Gramedia Pustaka Utama, Jakarta.

Bafadal Ibrahim. 2014. Pengelolaan Perpustakaan Sekolah. Bumi Aksara. Jakarta

Darmono. 2007. Pengembangan Perpustakaan Sekolah Sebagai Sumber Belajar. Jurnal Ilmu perpustakaan. Vol.11, No.2, h.3.

Fibriyanti, Yusi. 2013. Efektivitas Pemanfaatan Layanan Perpustakaan Sekolah Oleh Siswa Kelas VIII TH. Ajaran 2013/2014 SMPN 2 Kerjo Kab. Karanganyar, Jurnal, vol. 2, no 4, h. 41-48.

Ghozali, Imam. 2013, Aplikasi Analisis Nultivariate Dengan Program IBM SPSS 21, Cet. VII, Badan Penerbit UNDIP, Semarang.

Hernandono. 1999. Perpustakaan dan Kepustakaan: Universitas Terbuka. Jakarta

Mathar, Muh. Quraisy. 2012. Manajemen dan Organisasi Perpustakaan, Alauddin Press, Makassar.

Hurlock, Elizabeth B . 1997, Perkembangan Anak, Terjemahan Meitasari Tjandrasa, Erlangga, Jakarta.

Habir. 2015. Pengaruh Layanan Perpustakaan Terhadap Minat Kunjung Pemustaka Di Perpustakaan STIKES Mega Rezky Makassar. Jurnal Ilmu Perpustakaan, Informasi,Dankearsipan Khizanah Al-Hikmah, 3(2), 156-171.

Istiawan, Redhitya. 2014. Pemanfaatan Koleksi Perpustakaan Pada Mahasiswa di Perpustakaan Universitas Katolik Widya Mandala Surabaya. Jurnal Ilmu Perpustakaan, h.3.

IFLA/UNESCO, 2006, Pedoman Perpustakaan Sekolah, 
Keputusan Menteri Pendidikan dan Kebudayaan nomor 0103/O/1981, tanggal 11 Maret 1981 tentang perpustakaan sekolah.

Kotler, Philip. 2002. Manajemen Pemasaran di Indonesia : Analisis, Perencanaan, Implementasi dan Pengendalian. Salemba Empat. Jakarta.

Lasa Hs. 2009. Manajemen Perpustakaan Sekolah. Yogyakarta: Pinus Book Publisher.

Mashud, Rizka. 2014. Evaluasi Kualitas Layanan Perpustakaan. Yogyakarta: Uin $\quad$ Sunan

Kalijaga.

Nita, Chandra Hesti, 2014.Pemanfaatan Koleksi Buku Perpustakaan Sekolah Oleh Siswa Di SMA Negeri 1 Kalasan Kecamatan Kalasan, Skripsi,

Perpustakaan Nasional. 1992. Perpustakaan di Sekolah. Jakarta: Perpustakaan Nasional RI.

Supardi, 2005, Metode Penelitian Ekonomi Dan Bisnis, UII Perss, Yogyakarta.

Prawati, Budi. 2002, Keterampilan Koleksi, Majalah Ilmiah Pusat Perpustakaan Dan Penyebaran Teknologi Pertanian Oleh Peneliti Badan Litbang Pertanian.

Priyatna, Suganda. 1996, Motivasi, Partisipasi, dan Pembangunan: ditinjau dari sisi Komunikasi, UI press, Jakarta

Suherman. 2013. Perpustakaan Sebagai Jantung Sekolah.Referensi Pengelolaan Perpustakaan Sekolah. Bandung: Literate

Sugiyono, 2011. Metode Penelitian Administrasi, Cv Alfabeta, Bandung.

Saleh, Abdul Rahman. 2009. Manajemen Perpustakaan. Jakarta Universitas Terbuka.

Siregar, Sofyan, 2013. Metode penelitian kuantitatif dilengakapi dengan perbandingan perhitungan manual dan SPSS, kencana, Jakarta.

Sulastri, 2018. Analisis pengaruh daya tarik, kualitas pelayanan terhadap minat berkunjung ulang pengunjung yang berkunjung di mojosemi forest park kabupaten magetan. Jurnal Ekonomi, Manajemen dan Akuntansi, vol. 2, no. 1, h, 37-45.

Widaryono, 2017. Pengaruh Kualitas Layanan Sirkulasi Terhadap Kepuasan Pemustaka Pada Perpustakaan Smk-Pp Negeri Kupang, Jurnal Perpustakaan Pertanian, vol. 26, No.1, h.26-32.

Yusup, Pawit. 1995. Pedoman Praktis Mencari Infomasi. Bandung. PT. Remaja Rosdakarya. 